www.jmscr.igmpublication.org

Impact Factor 5.84

Index Copernicus Value: 71.58

ISSN (e)-2347-176x ISSN (p) 2455-0450

crossref DOI: _https://dx.doi.org/10.18535/jmscr/v5i11.44

Journal Of Medical Science And Clinical Research

IGM Publication

An Official Publication of IGM Publication

\title{
Expression of Stathmin and CD10 in Invasive Mammary Carcinoma with Relation to Triple Markers
}

\author{
Authors \\ Dr Niladri Sarkar ${ }^{1}$, Dr Anadi Roy Chowdhury ${ }^{2}$ \\ ${ }^{1}$ Junior Resident, ${ }^{2}$ Associate Professor \\ Department of Pathology, R.G. Kar Medical College and Hospital \\ Corresponding Author \\ Dr Niladri Sarkar \\ Department of Pathology, R.G. Kar Medical College and Hospital \\ 1, Khudiram Bose Road, Kolkata- 700004, West Bengal, India \\ Phone Number-8337036877, Email: drniladrisarkar26@gmail.com
}

\begin{abstract}
Background: Stathmin is a highly conserved cytosolic phosphoprotein that destabilizes microtubules. Stathmin acts in vitro as a tubulin-sequestering protein, and its activity is dramatically reduced by phosphorylation. It has a profound influence on cell proliferation, differentiation, and cellular motility. Similarly, CD10, a cell surface zinc dependent endopeptidase expression in tumor stroma is associated with aggressiveness of many epithelial malignancies.
\end{abstract}

Aims: The aims of this study were to estimate the frequency of expression of epithelial Stathmin and stromal CD10 in invasive breast cancers, and to assess the significance of epithelial Stathmin and stromal CD10 expression and its correlation with known prognostic markers of breast cancer.

Materials and Methods: The study conducted over a period of 12 months included 32 cases of breast carcinoma. Stathmin expression was assessed by immunohistochemistry and scored under four categories. CD10 expression was scored as negative, weakly positive and strongly positive.

Result: Stathmin was found to be positive in 24/32 (75\%) cases and CD10 was positive in stroma of 22/32 $(68.75 \%)$ cases. Epithelial Stathmin expression showed positive correlation with tumor grade and stage, negative correlation with ER and PR. Stromal CD10 showed positive correlation with tumor grade, stage and Her2neu, and negative correlation with ER and PR.

Conclusion: Stathmin and CD10 correlated strongly with well-established negative prognostic markers thus indicating that they can be used independent markers of poor prognosis and can be used as potential targets for the development of therapies.

Keywords: Breast carcinoma, Stathmin, CD10, hormone receptors, stromal marker, poor prognosis

\section{Introduction}

Breast cancer is one of the most common cancers among women globally ${ }^{1}$. Each tumor varies with respect to the malignant potential as well as the growth rate. Well established prognostic factors including stage of tumor, histological grade, lymph node status, ER/PR and Her2neu status are routinely studied in every case of breast cancer. ${ }^{2}$ 
Pathway specific therapy is the future of cancer management. The oncoprotein phosphatidyl inositol-3 kinase/PI3K is frequently activated in solid tumors including breast cancer. Aberrant PI3K loss of PTEN which is a negative regulator of this pathway results in robust activation of this pathway. Stathmin, a microtubule modelling cytosolic protein which has profound influence on cell proliferation, differentiation, and cellular motility is an accurate IHC marker for this signature pathway. ${ }^{3}$

Stathmin performs an important function in regulating rapid microtubule remodeling of the cytoskeleton in response to the cell's needs. Without tubulin polymerization, there is no microtubule assembly and thus cell cycle stoppage. Stathmin also promotes microtubule disassembly by acting directly on the microtubule ends. ${ }^{4}$

Stathmin shows anti PI3K pathway pharmacodynamics properties both in vitro and in vivo. Stathmin phosphorylation increases the concentration of tubulin available in the cytoplasm as cytokinesis, the last phase of the cell cycle, rapid dephosphorylation of Stathmin occurs to block the cell from entering back into the cell cycle until it is ready for microtubule assembly and thus increased mitosis. ${ }^{5}$ Another observation is Stathmin over expression in breast carcinoma seems to co relate with loss of Estrogen receptors and Progesterone receptors.

Although breast cancer is an epithelial malignancy arising in the epithelial cells of the terminal ductal lobular unit, the stroma surrounding the tumor is of utmost importance in deciding the tumor behavior and progression, thus studying its nature may contribute to finding new and effective methods of treatment. ${ }^{6,7}$ The continuous and bilateral molecular crosstalk between normal epithelial cells and cells of the stromal compartment is disrupted by several factors secreted by the tumor cells themselves or by stromal cells under the influence of cancer cells. ${ }^{6,8,9,10,11}$ One such important factor is the matrix metalloproteinase (MMPs). MMP plays an important role in tumor progression and in defining the role of stromal microenvironment in tumor invasion and metastasis. ${ }^{12}$ Cleavage products of matrix components and some growth factors have chemotactic activity for tumor cells, and thus help in tumor cell migration through matrix. ${ }^{13}$ This justifies the study of new stromal marker CD10 in the progression of invasive breast cancer.

In normal tissue, CD10 associates with the tumor suppressor PTEN leading to decreased PIP3 (phosphatidylinositol 3, 4, 5-triphosphate) phosphorylation, which prevents activation of the Akt pathway, and leads to cell apoptosis. CD10 also prevents cancer cell migration. In breast cancer, CD10 signaling could be modified in cancer progenitors or SCs, independently of its enzymatic activity. These signaling alterations could block PTEN functions leading to apoptosis inhibition, cell proliferation and angiogenesis through Akt pathway. This shows that's CD10 positivity is associated with increasing mitotic grade (i.e., increasing cell proliferation) and poor prognosis.

Another observation is that stromal expression of CD10 in breast cancer correlates with ER negativity and Her2 positivity. ${ }^{14}$

Another important role of Stathmin and CD10 is its role in the treatment of breast cancer. Stathmin expression can be used as an agent for microtubule targeting drugs like taxane and taxol in cancer treatment. ${ }^{15}$ From Stathmin expression one can get information about disease progression, prognosis, drug resistance and change in treatment modality. ${ }^{16}$ Treatment of breast cancer no longer depends on designing drugs against the cancer epithelial cells, but drugs that can have better delivery system, with maximum efficacy, least toxicity and that can modify the tumor microenvironment/ stroma. This had led to development of peptide prodrugs cleavable by peptidase present in the tumor environment, thus increasing maximum efficacy with least toxicity. CD10, being a cell surface metalloprotease expressed in the breast cancer, is capable of 
cleaving CPI-0004Na (a prodrug of doxorubicin) and related peptide prodrugs, such as N-succinylalanyl-L-isoleucyl-L-alanyl-L-leucyl-Dox

(sAIAL-Dox). ${ }^{17}$ This proteolytic cleavage generates leucyl-Dox, which is capable of entering cells and generating intracellular Dox, with a higher potency than Dox alone. Cytotoxicity of CPI-0004Na is inhibited by phosphoramidon, a known inhibitor of CD10 enzymatic activity. ${ }^{18}$

We will first study CD10 expression, Stathmin expression, ER expression, PR expression and Her-2-neu expression using immunohistochemistry in breast carcinoma and then compare the result with Estrogen receptor, Progesterone receptor and Her-2-neu expression in these patients. At the end of the study we will correlate CD10 and Stathmin as a severity marker related to pathological staging, grading and receptor evaluation.

\section{Material and Methods}

The study was conducted over a period of 12 months from July, 2016 to June, 2017. Mastectomy specimens were sent from the Operation Theatre of General Surgery Department to the Pathology Department along with duly filled up consent and case record form. Study group comprised of 32 cases of breast carcinoma.

After Gross examination was done, sections were processed and paraffin blocks were prepared. Subsequently six slides were cut from each.

Slide 1- Stained with hematoxylin and eosin.

Slide 2- Immunohistochemistry for estrogen receptor (Rabbit monoclonal antibody, Cell Marque)

Slide 3- Immunohistochemistry for progesterone receptor (Rabbit monoclonal antibody, Cell Marque)

Slide 4- Immunohistochemistry for Her2neu (Mouse monoclonal antibody, Cell Marque)

Slide 5- Immunohistochemistry for CD10 (Mouse monoclonal antibody, Dako)

Slide 6- Immunohistochemistry for Stathmin (Rabbit monoclonal antibody, Bio SB)
Estrogen receptor and Progesterone receptor expressions are measured with the help of Allred scoring method which is based on the assessment of the proportion and intensity of staining:

\begin{tabular}{|lccc|}
$\begin{array}{l}\text { Allred } \\
\text { Scoring }\end{array}$ & $\begin{array}{c}\text { Positive cells, } \\
\text { \% }\end{array}$ & Intensity & $\begin{array}{c}\text { Intensity } \\
\text { Score }\end{array}$ \\
\hline $\mathbf{0}$ & 0 & None & 0 \\
\hline $\mathbf{1}$ & $<1$ & Weak & 1 \\
\hline $\mathbf{2}$ & 1 to 10 & Intermediate & 2 \\
\hline $\mathbf{3}$ & 11 to 33 & Strong & 3 \\
\hline $\mathbf{4}$ & 34 to 66 & Total Score 0-8 \\
\hline $\mathbf{5}$ & $\geq 67$ & Negative $\leq \mathbf{2 , \text { Positive 3-8 }}$ \\
\hline
\end{tabular}

Her2-neu scoring is done based on the staining pattern as per the following chart:

\begin{tabular}{|lll|}
$\begin{array}{c}\text { Score to } \\
\text { report }\end{array}$ & $\begin{array}{c}\text { Her2 protein } \\
\text { over expression } \\
\text { assessment }\end{array}$ & \multicolumn{1}{c|}{ Staining pattern } \\
\hline $\mathbf{0}$ & Negative & $\begin{array}{l}\text { No staining is observed, or membrane } \\
\text { staining in less than } 10 \% \text { of tumour cells }\end{array}$ \\
\hline $\mathbf{1 +}$ & Negative & $\begin{array}{l}\text { A faint/barely perceptible membrane } \\
\text { staining is detected in more than } 10 \% \text { of } \\
\text { tumour cells. The cells are only stained } \\
\text { in part of the membrane }\end{array}$ \\
\hline $\mathbf{2 +}$ & Borderline & $\begin{array}{l}\text { A weak to moderate complete } \\
\text { membrane staining is observed in more } \\
\text { than } 10 \% \text { of tumour cells }\end{array}$ \\
\hline $\mathbf{3 +}$ & Positive & $\begin{array}{l}\text { A strong complete membrane staining is } \\
\text { observed in more than 10\% of the } \\
\text { tumour cells }\end{array}$ \\
\hline
\end{tabular}

Stathmin scoring was done as follows:

\begin{tabular}{|l|c|c|}
\hline Score to report & Stathmin assessment & Staining pattern \\
\hline $\mathbf{0}$ & Negative & No expression \\
\hline $\mathbf{1}$ & Low & $<10 \%$ tumor cells \\
\hline $\mathbf{2}$ & Medium & $10-50 \%$ tumor cells \\
\hline $\mathbf{3}$ & High & $>50 \%$ tumor cells \\
\hline
\end{tabular}

CD10 scoring was done as follows:

\begin{tabular}{|lc|}
\hline Score to report & CD10 Staining \\
\hline Negative & $<10 \%$ stromal positive cells \\
\hline Weakly positive & $10-30 \%$ stromal positive cells \\
\hline Strongly positive & $>30 \%$ stromal positive cells \\
\hline
\end{tabular}

Statistical analysis was done by using SPSS and P values less than 0.05 were considered significant.

\section{Results}

$39 \%$ of the cases belonged to the age group of 41 50 years. Most of our cases belonged to Stage III categories $(22 / 32 ; 68.75 \%)$. All the cases of our study comprised of invasive ductal carcinoma, not otherwise specified (NOS). Bloom and Richardson grading was performed on all the cases and most of them belonged to Grade $2(16 / 32 ; 50 \%)$ while 10/32 (31.25\%) cases were Grade 3. Immunohistochemistry was done on all the 32 cases. There was no expression of CD10 in 
normal ductal cells, adipose cells and fibroblasts, although the non-neoplastic myoepithelial cells, wherever present served as an internal positive control. Stathmin expression was seen in neoplastic ductal cells with tonsil taken as positive control.

CD10 was found to be positive in $68.75 \%$ of cases (22/32) with 15 (46.9\%) cases showed strong positivity. A positive correlation was observed between CD10 and histopathological grade and the study was statistically significant $(\mathrm{p}=.000)$. Similarly, higher was the Stage of the tumor, stronger was the CD10 expression with 14 cases of Stage III tumor showing strong positivity. This was also statistically significant $(\mathrm{p}=0.01)$. A negative statistical significance was found between CD10 and ER/PR ( $\mathrm{p}=.000)$. With increasing CD10 positivity from weak to strong, ER/PR negativity increased from $21.9 \%$ to $46.9 \%$. CD10 when compared with Her2neu, it was statistically significant and there was a positive correlation of 0.648

Stathmin was found to be positive in 24 cases (75\%). Higher the grade of the tumor, higher was the Stathmin grade with $63.63 \%$ high tumor grade showed Grade 3 Stathmin expression. This was statistically significant $(\mathrm{p}=.017)$. Stathmin showed a statistically positive correlation with the Stage of the tumor $(\mathrm{p}=0.28)$. Stathmin showed a negative correlation with ER/PR and the study was significant $(p=.000)$. Stathmin showed a negative correlation with Her2neu however it was not statistically significant.

Table 1: Correlation between CD10 and parameters

\begin{tabular}{|lcccc|}
\hline PARAMETERS & \multicolumn{3}{c}{ CD 10 GRADE } & P Value \\
\hline NEGATIVE & $\begin{array}{c}\text { WEAKLY } \\
\text { POSITIVE }\end{array}$ & $\begin{array}{c}\text { STRONGLY } \\
\text { POSITIVE }\end{array}$ & \\
\hline Stage II & & $1(3.13 \%)$ & $1(3.13 \%)$ & $<\mathbf{0 . 0 0 1}$ \\
Stage III & $8(25 \%)$ & $6(18.75 \%)$ & $14(43.75 \%)$ & \\
Tumour Grade & $2(6.25 \%)$ & & $<0.001$ \\
Grade 1 & $5(15.6 \%)$ & $1(3.13 \%)$ & $0(0.0 \%)$ & \\
Grade 2 & $5(15.6 \%)$ & $5(15.6 \%)$ & $6(18.75 \%)$ & \\
Grade 3 & $0(0.0 \%)$ & $1(3.13 \%)$ & $9(28.13 \%)$ & \\
Estrogen Receptor & $8(25 \%)$ & $2(6.25 \%)$ & $2(6.25 \%)$ & $\mathbf{0 . 0 0 4}$ \\
Positive & $2(6.25 \%)$ & $5(15.6 \%)$ & $13(40.63 \%)$ & \\
Negative & $8(25 \%)$ & $2(6.25 \%)$ & $2(6.25 \%)$ & $\mathbf{0 . 0 0 4}$ \\
Progesterone Receptor & $2(6.25 \%)$ & $5(15.6 \%)$ & $13(40.63 \%)$ & \\
Positive & & & \\
Negative & $2(6.25 \%)$ & $6(18.75 \%)$ & $13(40.63 \%)$ & \\
Her2neu & $8(25 \%)$ & $1(3.13 \%)$ & $2(6.25 \%)$ & \\
Positive & & & \\
Negative & & & \\
\hline
\end{tabular}

Bold $\mathrm{P}$ values are significant $(\mathrm{P}<0.05)$

Table 2: Correlation between CD10 and parameters

\begin{tabular}{|c|c|c|c|c|c|}
\hline \multirow[t]{2}{*}{ PARAMETERS } & \multicolumn{4}{|c|}{ STATHMIN GRADE } & \multirow[t]{2}{*}{ P Value } \\
\hline & NEGATIVE & GRADE 1 & GRADE 2 & GRADE 3 & \\
\hline STAGE & & & & & 0.028 \\
\hline Stage II & $5(15.6 \%)$ & $3(9.38 \%)$ & $1(3.13 \%)$ & $1(3.13 \%)$ & \\
\hline Stage III & $3(9.38 \%)$ & $2(6.25 \%)$ & $7(21.88 \%)$ & $10(31.25 \%)$ & \\
\hline Tumour Grade & & & & & 0.017 \\
\hline Grade 1 & $3(9.38 \%)$ & $3(9.38 \%)$ & $0(0 \%)$ & $0(0 \%)$ & \\
\hline Grade 2 & $5(15.6 \%)$ & $2(6.25 \%)$ & $5(15.6 \%)$ & $4(12.5 \%)$ & \\
\hline Grade 3 & $0(0 \%)$ & $0(0 \%)$ & $3(9.38 \%)$ & $7(21.88 \%)$ & \\
\hline Estrogen Receptor & & & & & $<0.001$ \\
\hline Positive & $4(12.5 \%)$ & $1(3.13 \%)$ & $2(6.25 \%)$ & $1(3.13 \%)$ & \\
\hline Negative & $4(12.5 \%)$ & $4(12.5 \%)$ & $6(18.75 \%)$ & $10(31.25 \%)$ & \\
\hline Progesterone Receptor & & & & & $<0.001$ \\
\hline Positive & $4(12.5 \%)$ & $1(3.13 \%)$ & $2(6.25 \%)$ & $1(3.13 \%)$ & \\
\hline Negative & $4(12.5 \%)$ & $4(12.5 \%)$ & $6(18.75 \%)$ & $10(31.25 \%)$ & \\
\hline Her2neu & & & & & 0.083 \\
\hline Positive & $2(6.25 \%)$ & $3(9.38 \%)$ & $6(18.75 \%)$ & $10(31.25 \%)$ & \\
\hline Negative & $6(18.75 \%)$ & $2(6.25 \%)$ & $2(6.25 \%)$ & $1(3.13 \%)$ & \\
\hline
\end{tabular}

Bold $\mathrm{P}$ values are significant $(\mathrm{P}<0.05)$ 


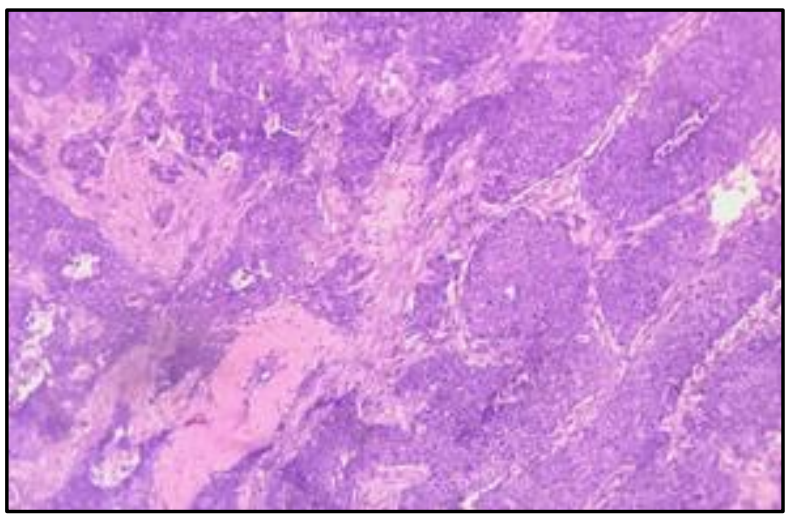

Figure 1:Invasive ductal carcinoma on histopathology (H\&E Stain, 100x)
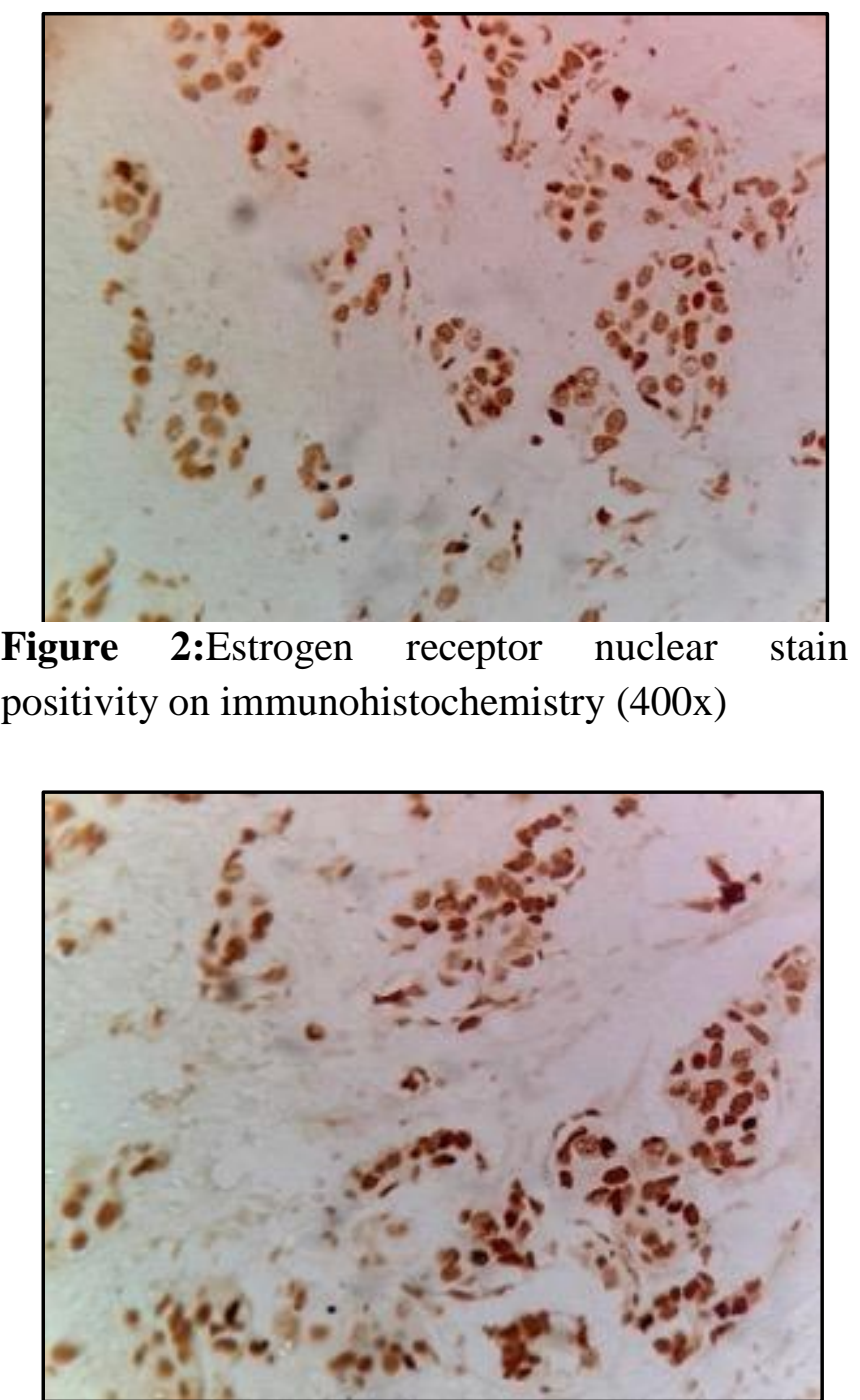

Figure 3: Progesterone receptor nuclear stain positivity on immunohistochemistry (400x)

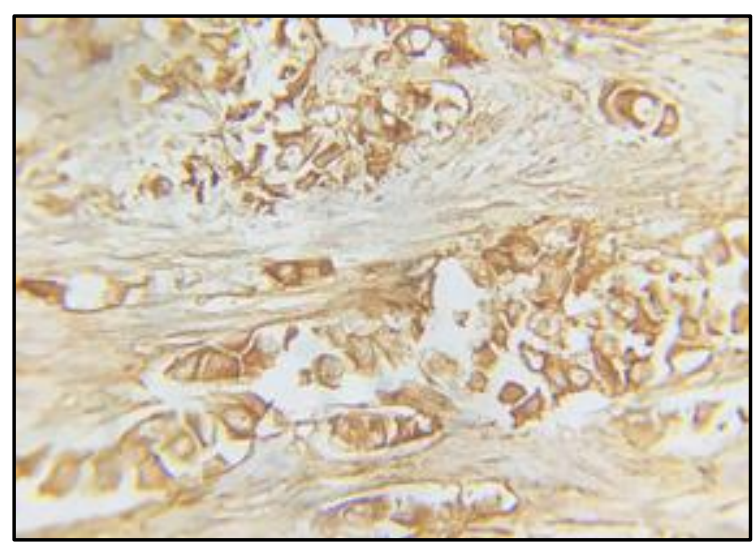

Figure 4:Her2neu membrane stain positivity on immunohistochemistry (400x)

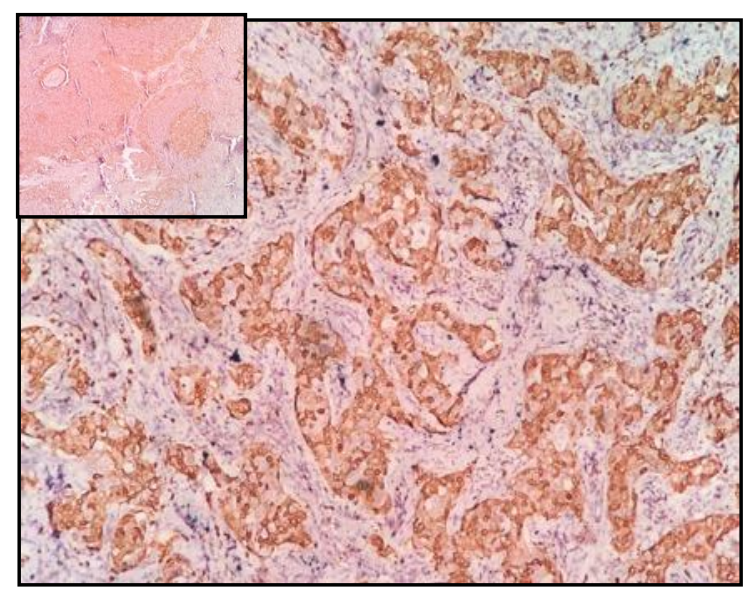

Figure 5: Stathmin Grade 3 on immunohistochemistry (100x); inset showing positive control (tonsil)

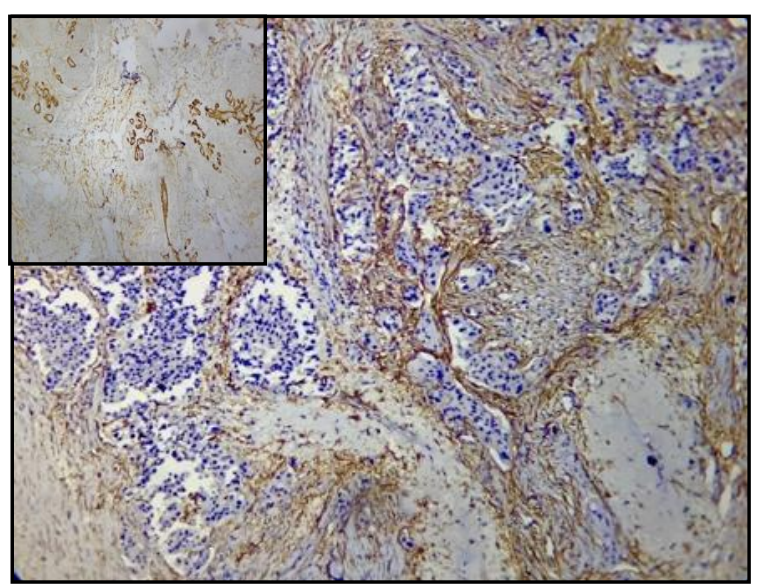

Figure 6: CD10 Strong positivity on immunohistochemistry (100x); inset showing positive internal control 


\section{Discussion}

Agarwal $G$ and Ramakant $P^{19}$ found in their studies that almost $50 \%$ of patients present with locally advanced disease. The majority of patients present with stage III-b (35\%) and III-a (27\%). Quite a few patients have large operable breast cancers and stage II-b (16\%). Some $8-10 \%$ of patients have TNM stage IV disease at presentation, and only very few (approximately $5 \%$ ) have stage I disease. In our study population of 32 cases we found that $69 \%$ cases (22 cases) were Stage III and $31 \%$ cases (10 cases) were Stage II. There are no Stage I cases.

$\mathrm{C} \mathrm{W}$ Elston et $\mathrm{al}^{20}$ in their study found that Morphological assessment of the degree of differentiation has been shown in numerous studies to provide useful prognostic information. Histological grade, assessed in 1831 patients, shows a very strong correlation with prognosis; patients with grade I tumors have a significantly better survival than those with grade II and grade III tumors. In our study population of 32 cases we found that Histopathological Grade 3 cases were $31 \%$ (10), Histopathological Grade 2 cases were $50 \%$ (16) and Histopathological Grade 1 cases were $19 \%$.

Markretsov et $\mathrm{al}^{21}$ concluded that CD10 strong response was more with higher grade tumors and estrogen receptor negativity compared to lower grade tumors and estrogen receptor positivity. Our study also showed a similar trend with a positive correlation to tumor grade and estrogen receptor negativity.

$\mathrm{S}$ Thomas $\mathrm{Babu}$ et $\mathrm{al}^{22}$ concluded that strong CD10 expression correlates with hormone receptor negativity and HER-2/neu overexpression. This is in accordance to our study with a positive correlation with Her2neu overexpression $(\mathrm{p}=.000)$.

The study between Stathmin and Staging is statistically significant and concordant with the research of Soerjomataram et $\mathrm{al}^{23}$. As the Stathmin grade increased from 0 to 3 , the number of cases of Stage III cases also increased considerably compared to Stage II cases. G. Brattsand et $\mathrm{al}^{24}$ concluded that Oncoprotein 18/Stathmin (Op18) is a conserved cytosolic phosphoprotein that regulates microtubule dynamics. Op18 levels were negatively correlated with estrogen receptor (ER) expression and positively correlated with a high fraction of aneuploid cells, proliferation measured by proliferating cell nuclear antigen (PCNA) expression, tumor size and histopathologic grade. This is in accordance to our study showing a negative correlation with estrogen receptor expression $(\mathrm{p}=.000)$. Cianfrocca et $\mathrm{al}^{25}$ found in their studies that hormone receptors and HER2/neu overexpression, are both prognostic and predictive. Our study showed a positive correlation, however it was not statistically significant $(p=0.083)$. This may be due to sampling error because of small number of cases.

\section{Conclusion}

To conclude, CD10 and Stathmin expression strongly correlated with well-established negative prognostic marker that is ER/PR negativity, Her2neu positivity, and higher tumor stage and grade. This study gives substantial proof to several research papers explaining the role of stroma/CD10 and epithelial cell marker Stathmin in breast cancer pathogenesis, and in predicting prognosis and tumor response. Keeping the role of these two markers, CD10 and Stathmin should be included as a routine pre-chemotherapy marker in breast carcinoma.

\section{References}

1. Juan Rosai, et al. The Breast: Ackerman's Surgical pathology, $10^{\text {th }}$ edition,2011, Elsevier publication, volume 2, page 1661.

2. Sørlie T, Perou CM, Tibshirani R, et al. Gene expression patterns of breast carcinomas distinguish tumor subclasses with clinical implications, Proc Natl AcadSci U S A. 2001;98(19):10869-74.

3. Saala L H, Johanssonc P, Holm K, S K, Saala G, Shed Q B, Maurera M, Koujaka S, Ferrandoa A, Malmstrom A, et al. Poor prognosis in carcinoma is associated with a 
gene expression signature of aberrant PTEN tumor suppressor pathway activity, PNAS May 1, 2007 vol. 104 no.18, page7564

4. Jourdain L, Curmi P, Sobel A, Pantaloni D, Carlier MF, Stathmin: a tubulinsequestering protein which forms a ternary T2S complex with two tubulin molecules,Biochemistry. $1997 \quad$ Sep 9;36(36):10817-21

5. Manna T, Thrower DA, Honnappa S, Steinmetz MO, Wilson L, et al. Regulation of microtubule dynamic instability in vitro by differentially phosphorylated Stathmin, J Biol Chem. 2009 Jun 5;284(23):15640-9. doi: 10.1074/jbc.M900343200. Epub 2009 Apr 8.

6. Mott JD, Werb Z, et al. Regulation of matrix biology by matrix metalloproteinases. CurrOpin Cell Biol 2004; 16:55864.

7. Fidler IJ, et al. The pathogenesis of cancer metastasis: The 'seed and soil' hypothesis revisited, Nat Rev Cancer 2003;3:453-8.

8. Bremnes RM, Dønnem T, Al-Saad S, AlShibli K, Andersen S, Sirera R, et al. The role of tumor stroma in cancer progression and prognosis: Emphasis on carcinomaassociated fibroblasts and non-small cell lung cancer. J ThoracOncol 2011; 6:20917.

9. De Wever O, Mareel M, et al. Role of tissue stroma in cancer cell invasion. $\mathbf{J}$ Pathol 2003; 200:429-47.

10. Pollard JW, et al. Tumour-educated macrophages promote tumour progression and metastasis. Nat Rev Cancer 2004; 4:71-8.

11. Jinga DC, Blidaru A, Condrea I, Ardeleanu C, Dragomir C, Szegli G, et al. MMP-9 and MMP-2 gelatinases and TIMP-1 and TIMP-2 inhibitors in breast cancer: Correlations with prognostic factors. J Cell Mol Med 2006; 10:499-510.
12. Curran CS, Keely PJ, et al. Breast tumor and stromal cell responses to TGF- $\beta$ and hypoxia in matrixdeposition. Matrix Biol 2013; 32:95-105

13. Kass L, Erler JT, Dembo M, Weaver VM, et al. Mammary epithelial cell: Influence of extracellular matrix composition and organization during development and tumorigenesis.Int $\mathrm{J}$ Biochem Cell Biol 2007; 39:1987-94.

14. Ellis H, Colborn GL, Skandalakis JE, et al. Surgical embryology and anatomy of the breast and its related anatomic structures. SurgClin North Am 1993; 73:611-632.

15. Sean Lawler, et al. Microtubule dynamics: If you need a shrink try Stathmin, Op18, Current Biology, Volume 8, Issue 6, 12 March 1998, Pages R212-R214.

16. Sherbet GV and Cajone F, Stathmin in Cell Proliferation and Cancer Progression, Cancer Genomics and Proteonomics 2: 237-238 (2005).

17. Pan C, Cardarelli PM, Nieder MH, Pickford LB, Gangwar S, King DJ, et al. CD10 is a key enzyme involved in the activation of tumor-activated peptide prodrug CPI-0004Na and novel analogues: Implications for the design of novel peptide prodrugs for the therapy of CD10+ tumors. Cancer Res 2003; 63:5526-31.

18. Desmedt C, Majjaj S, Kheddoumi N, Singhal SK, Haibe-Kains B, El Ouriaghli $\mathrm{F}$, et al. Characterization and clinical evaluation of $\mathrm{CD} 10+$ stroma cells in the breast cancer microenvironment. Clin Cancer Res 2012; 18:1004-14.

19. Gaurav Agarwal, Pooja Ramakant, et al. Breast Cancer Care in India: The Current Scenario and the Challenges for the Future, Breast care(Basel). 2008 Mar; 3(1): 21-27

20. C.W. Elston, I.O.Ellis, et al. Pathological prognostic factors in breast cancer. The value of histological grade in breast cancer: experience from a large study with 
long-term follow-up, Histopathology

Journal (1991)19, 403-4.

21. Makretsov NA, Hayes M, Carter BA, Dabiri S, Gilks CB, Huntsman DG, et al. CD10 expression in invasive breast carcinoma correlates with poor prognosis, estrogen receptor negativity, and high grade. NCBI Mod Pathol 2007; 20:84-9.

22. Thomas S, Babu RJ, Agarwal K, Puri V, Jain M, Andley $M$, et al. Effect of neoadjuvant chemotherapy on stromal CD10 antigens in breast cancer - a preliminary study. Indian J Cancer 2013; 50:46-51.

23. Isabelle Soerjomataram, Marieke W. J. Louwman, Jacques G. Ribot, Jan A. Roukema,Jan Willem W. Coebergh, et al. An overview of prognostic factors for long-term survivors of breast cancer, Breast Cancer Res Treat (2008) 107:309330.

24. Brattsand G, et al. Op 18 in breast cancer, British Journal of Cancer (2000) 83(3), 311-318.

25. Mary Cianfrocca, Lori J Goldstein, et al. Prognostic and Predictive Factors in EarlyStage Breast Cancer, The Oncologist 2004;9:606-616. 